\title{
Use of Glutamine in Post-Hatch Feed for Broiler Chicks
}

http://dx.doi.org/10.1590/1806-9061-2019-1120

\section{-Author(s)}

Carvalho FB' (iD https://orcid.org/0000-0001-5900-5437 Stringhini JH" (DD https://orcid.org/0000-0002-3710-6963 Leandro NSM" (iD https://orcid.org/0000-0002-6525-9975 Café M" (iD) https://orcid.org/0000-0002-1478-8009 Sousa RF" (iD https://orcid.org/0000-0002-9439-843X Santos BM"II (D) https://orcid.org/0000-0001-5722-9824 Universidade Federal de Goias Escola de Veterinaria e Zootecnia Ringgold standard institution - Departamento de Zootecnia - Rua 132A, Qd 45, lote 05 Goiânia, Goiânia, GO 74690-900, Brazil.

" Universidade Federal de Goiás Escola de Veterinária e Zootecnia Ringgold standard institution - Departamento de Zootecnia Avenida Esperança, $s / n$, Campus Samambaia Goiania, Goiás 74.690.900, Brazil.

III Faculdade União de Goyazes, Rodovia GO-060 3184 - Laguna Park, Trindade 75380-000, Brasil.

\section{ABSTRACT}

Post-hatch delayed placement damages, physical and physiological development of broiler chicks. The objective of this study was to ascertain adequate levels of glutamine inclusion in post-hatch and prestarter feed, in order to minimize the negative effects of post-hatch delayed placement on broiler chicks. The birds were distributed in a completely randomized design, with four treatments and five replicates of ten birds each. Four levels of glutamine supplementation $(0,1,2$ and $3 \%$ ) were used in the pre-starter feed, which was given to the chicks in the transportation box and during the pre-starter phase. After 24 hours of access to this feed, and at 7 days of age, the chicks' performance, yolk sac retraction, plasma glucose concentration, weight and small-intestine histomorphometry were evaluated. From seven to ten days of age, a metabolizability assay was performed. Glutamine supplementation tended to increase the use of the yolk sac, the concentration of plasma glucose $(p<0.10)$ and the depth of the crypt in the ileum after 24 hours of life $(p<0.05)$. There was no statistical difference between the glutamine supplementation levels, in relation to glucose, histomorphometry or metabolizability in the pre-starter phase. Glutamine concentrations did not differ in relation to performance, histomorphometry of the small intestine or metabolizability of nutrients in the pre-starter phase.

\section{INTRODUCTION}

The post-hatch period is considered to be a critical time for broiler chicks. It is a phase of adaptation to the environment external to the egg and specially to feed coming from exogeneous sources. What makes this period even more difficult is the fasting that these chicks undergo.

Because of standard incubator procedures, chicks do not have access to feed for a period of approximately 48 hours, from their hatching until their placement, which could mean they do not have access to feed for two or three days (Bhuiyan et al., 2011). Delayed intake of feed can consequently hinder physiological and immunological development, thus reducing the overall productivity of chick-rearing (Van Den Brand et al., 2010).

Specific formulations are used for feed in the post-hatch and prestarter phases of broiler chicks. These include the presence of trophic agents to attenuate the undesirable effects of post-hatch fasting, with aim to achieve greater precocity in the physical and physiological development of broiler chicks.

Glutamine is among the possible trophic agents used. The importance of this substance is mainly in relation to the intestinal development of broiler chickens, such that it leads to greater use of nutrients from their diets, especially among birds that are exposed to 
unfavorable conditions. Pelícia et al. (2015) observed a significant increase in the height of villi and depth of crypts through supplementation with glutamine in the diets of broiler chickens at the age of seven days.

Several studies on glutamine supplementation for broiler chickens have been conducted, but there is still little information regarding the possible use and benefits of this amino acid in the post-hatch and pre-starter phases, or regarding what the best supplementation to use during these phases might be.

In this light, the objective of the present study was to ascertain the appropriate levels of glutamine inclusion in post-hatch and pre-starter feed, from the perspectives of minimizing the negative effects of post-hatch delayed placement and ensuring intestinal integrity and nutritional support for these chicks.

\section{MATERIAL AND METHODS}

The experiment was approved by the Ethics Committee on the Use of Animals (CEUA) under protocol no. 008/13.

The treatments consisted of four levels of supplementation $(0,1,2$ and $3 \%)$ of glutamine in the pre-starter feed. The experimental feeds were created from a baseline feed (Table 1), through adding doses of glutamine as a substitute for starch.

Table 1 - Composition and values calculated (\%) for the baseline feed.

\begin{tabular}{|c|c|c|c|c|}
\hline \multirow{2}{*}{$\begin{array}{l}\text { Ingredients } \\
\% \text { of glutamine }\end{array}$} & \multicolumn{4}{|c|}{ Pre-starter feed 1 to 7 days } \\
\hline & 0 & 1 & 2 & 3 \\
\hline Corn & 51.06 & 51.06 & 51.06 & 51.06 \\
\hline Soybean meal & 39.50 & 39.50 & 39.50 & 39.50 \\
\hline Soybean oil & 2.35 & 2.35 & 2.35 & 2.35 \\
\hline Calcitic limestone & 0.88 & 0.88 & 0.88 & 0.88 \\
\hline Dicalcium phosphate & 1.94 & 1.94 & 1.94 & 1.94 \\
\hline L-lysine & 0.20 & 0.20 & 0.20 & 0.20 \\
\hline DL-methionine & 0.25 & 0.25 & 0.25 & 0.25 \\
\hline Threonine & 0.10 & 0.10 & 0.10 & 0.10 \\
\hline Sodium bicarbonate & 0.19 & 0.19 & 0.19 & 0.19 \\
\hline Table salt & 0.39 & 0.39 & 0.39 & 0.39 \\
\hline Vitamin supplement ${ }^{1}$ & 0.10 & 0.10 & 0.10 & 0.10 \\
\hline Mineral supplement ${ }^{2}$ & 0.05 & 0.05 & 0.05 & 0.05 \\
\hline Glutamine & 0.00 & 1.00 & 2.00 & 3.00 \\
\hline Starch & 3.00 & 2.00 & 1.00 & 0.00 \\
\hline Total & 100.00 & 100.00 & 100.00 & 100.00 \\
\hline \multicolumn{5}{|l|}{ Calculated composition } \\
\hline Metabolizable energy $(\mathrm{kcal} / \mathrm{kg})$ & 2951.00 & 2950.00 & 2949.00 & 2947.00 \\
\hline Crude protein (\%) & 22.280 & 23.478 & 24.676 & 25.870 \\
\hline Calcium (\%) & 0.922 & 0.922 & 0.922 & 0.922 \\
\hline Available phosphorus (\%) & 0.471 & 0.471 & 0.471 & 0.471 \\
\hline Methionine (\%) & 0.542 & 0.542 & 0.542 & 0.542 \\
\hline Methionine + cystine (\%) & 0.850 & 0.850 & 0.850 & 0.850 \\
\hline Lysine (\%) & 1.312 & 1.312 & 1.312 & 1.312 \\
\hline Threonine (\%) & 0.852 & 0.852 & 0.852 & 0.852 \\
\hline Sodium (\%) & 0.223 & 0.223 & 0.223 & 0.223 \\
\hline Chlorine (\%) & 0.283 & 0.283 & 0.283 & 0.283 \\
\hline
\end{tabular}

${ }^{1}$ Vitamin supplement - guaranteed level per kilogram of product: 3,125,000 IU of vitamin A; 550,000 IU of vitamin D3; 3,750 mg of vitamin E; 625 mg of vitamin K3; 250 mg of vitamin B1; 1, $125 \mathrm{mg}$ of vitamin B2; $250 \mathrm{mg}$ of vitamin B6; 3,750 mg of vitamin B12; 9,500 mg of niacin; 3,750 mg of calcium pantothenate; $125 \mathrm{mg}$ of folic acid; $350,000 \mathrm{mg}$ of DL-methionine; $150,000 \mathrm{mg}$ of choline chloride $50 \% ; 50 \mathrm{mg}$ of selenium; 2,500 mg of antioxidant; and 1,000 g of vehicle q.s.p.

${ }^{2}$ Mineral supplement - guaranteed levels per kilogram of product: manganese, 150,000 mg; zinc, 100,000 mg; iron 1,00,000 mg; copper, 16,000 mg; and iodine, 1,500 mg.

The pre-starter feed (Table 1) was formulated using corn and soybean meal, following the recommendations for nutritional demands and feed composition proposed by Rostagno et al. (2005).

A total of 1,200 male chicks of the Cobb 500 strain were used. These chicks originated from eggs produced by laying hens that were all of similar age, and their eggs were incubated in the same machine.

After a birth window of 12 hours, the chicks were removed from the hatchery. They were vaccinated and sexed, following the standard procedures of the hatchery, and were then transported to the aviary. All 
Carvalho FB, Stringhini JH, Leandro NSM, Café M, Sousa RF, Santos BM

\section{Use of Glutamine in Post-Hatch Feed for Broiler Chicks}

procedures conducted with the chicks, from hatching until housing, lasted 24 hours.

The birds were distributed in the aviary following a completely randomized design. There were four treatments, with five replicates of 60 birds each, in the transportation boxes, which received $3 \mathrm{~g} / \mathrm{bird}$ of prestarter feed for consumption over 24 hours. During this 24-hour period, the chicks did not receive water, thus simulating what happens in the hatchery. After 24 hours of experimental feed consumption, 10 chicks per replicate, according to the average plot weight, were transferred to galvanized steel cages equipped with linear feeders and water dispensers. The chicks continued to receive the experimental feed in the cages until they reached seven days of age.

Water and feed were offered freely over the whole rearing period, with a 24-hour light cycle. The temperature of the environment was monitored twice a day (8:00 AM and 5:00 PM) using maximum and minimum thermometers within the shed. The mean maximum temperature during the experiment was $33.47^{\circ} \mathrm{C}$, while the mean minimum temperature was $25.48^{\circ} \mathrm{C}$.

To assess the effect of the experimental feed, the chicks underwent body weighing, weighing of the yolk sac and intestine, collection of fragments from the duodenum, jejunum and ileum, and measurement of glucose concentration over three stages of the experiment. The first sampling took place as soon as the 24-hour birth window closed and involved 15 chicks as a control group (mean body mass 44.54 $\mathrm{g}$, mean yolk sac mass $5.87 \mathrm{~g}$, mean intestine mass $1.87 \mathrm{~g}$ and blood glucose of 348.2); the second time was after the 24 hours within the transportation box, before the chicks were housed, with sampling of five birds per treatment; and the third sampling was conducted when the chicks completed seven days of life, again including five birds per treatment.

Weight gain was calculated as the difference between the final and initial weights. Feed consumption was calculated as the difference between the feed supplied and the leftovers at the end of each phase. Feed conversion was obtained through the ratio of feed consumption/weight gain. Viability was assessed through the formula $\mathrm{V}(\%)=100$ - mortality.

Glucose concentration was assessed through analysis within thirty seconds after drawing blood, using portable glucose metering equipment.

Five birds from each treatment were euthanized to evaluate intestinal development and yolk sac retraction.
The yolk sac and intestines (small and large) were then weighed on a scale with precision of $0.0001 \mathrm{~g}$.

One chick per replicate was used for histomorphometric assessment of the small intestine. Two-centimeter fragments were collected from the duodenum, jejunum and ileum, and were fixed in buffered 10\% formaldehyde for 24 hours. These samples were then subjected to standard histological procedures to produce histological slides. The sections were stained with hematoxylin and eosin (Hu et al., 2012; Sousa et al., 2015). The heights of 10 villi and the depths of 10 crypts were measured on each section.

A metabolic assay was conducted between the ages of seven and 10 days, using the total fecal collection method. Excreta were collected twice a day (8:00 AM and 5:00 PM), stored in plastic bags (which were identified according to the replicate) and kept in a freezer. At the end of the experimental period, the amount of feed consumed was determined, along with the total amount of fecal material produced. The quantities of excreta and experimental feed were used to determine the dry matter, nitrogen and ether extract content, as described by Silva \& Queiroz (2002).

The results from bromatological analyses were used to calculate metabolizability coefficients (MC) for dry matter (MCDM), nitrogen (MCN) and ether extract (MCEE). Nitrogen balance (NB) and ether extract balance (EEB) were also calculated, using the formula: $M C(\%)=($ nutrient $B /$ nutrient ingested $\mathrm{DM}(\mathrm{g})) \times 100$

Where nutrient $\mathrm{B}(\mathrm{g})=$ nutrient ingested - nutrient excreted

Variance analysis was performed to assess the significance of treatment effects using the SAEG statistical program (2007). Having significance, the polynomial regression analysis $(p<0.05)$ was applied, although $p$ values between 0.05 and 0.10 are shown and described as trend.

\section{RESULTS AND DISCUSSION}

Descriptive presentation of the values of the live weights of the chicks before and 24 hours after the experimental ration, and the amounts of feed consumed for a better understanding of the subsequent results are shown in (Table 2). The values showed that the chicks consumed little amount of feed and, therefore, presented an average weight loss of $2.63 \mathrm{~g}$ during the period of 24 hours inside the transport boxes. 
Table 2 - Mean weight loss and consumption of pre-starter feed supplemented with glutamine that was given to recently hatched chicks while they were in transportation boxes.

\begin{tabular}{lcccc}
\hline Treatment & Weight before $(\mathrm{g})$ & Weight after 24 hours $(\mathrm{g})$ & Weight loss $(\mathrm{g})$ & Feed consumption $(\mathrm{g})$ \\
\hline Glutamine & \multicolumn{4}{c}{} \\
\hline $0 \%$ & 45.45 & 42.90 & 2.55 & 0.009 \\
$1 \%$ & 45.81 & 43.31 & 2.49 & 0.026 \\
$2 \%$ & 45.43 & 42.60 & 2.83 & 0.010 \\
$3 \%$ & 45.33 & 42.68 & 2.65 & 0.012 \\
\hline Mean & 45.50 & 42.87 & 2.63 & 0.014 \\
\hline
\end{tabular}

The fact that the chicks did not have access to water during this period may have been an aggravating factor for weight loss. The reduction in live weight of the chicks during this phase occurs due to higher use of energy reserves from the yolk sac, digestive and renal excretions, and dehydration (Leu et al., 2002; Carvalho et al., 2013).

Values for the live weight of the chicks, retraction of the yolk sac, small intestine weight and glucose levels (Table 3).

Although consumption of the experimental feed in the transportation boxes was low, there was a tendency to greater retraction of the yolk sac $(p=0.096)$ with increasing glutamine supplementation $(Y=3.94450-$ $1.152850 X+0.384500 X^{2} ; R^{2}=0.99$, quadratic effect). There was improvement in the use of the yolk sac until reaching glutamine supplementation of $1.49 \%$. Bhanja et al. (2009) observed greater reduction of yolk sacs in birds that were fed immediately after hatching, thus suggesting that feed consumption might increase the mechanical activity of the intestine, such that the yolk sac would be absorbed more rapidly.

There was a tendency for blood glucose concentration to increase $(p=0.098)$, with glutamine supplementation, up to $1.81 \% \quad(Y=296.930+$ 51.4300X - 14.1500X $X^{2} ; R^{2}=0.99$, quadratic effect).

Fasting chicks go through a critical gluconeogenic metabolism period, with increases in ketosis and dehydration. Quick supplying of feed could minimize these effects, through altering the glycemic pattern of these birds (Vieira \& Moran, 1999). Gluconeogenesis decreases as the plasma glucose concentrations increase through consumption of feed. Metabolizing of glutamine through the renal system may supply up to $25 \%$ of the glucose circulating in the plasma (Ribeiro Junior et al., 2015).

Table 3-Evaluation of yolk sac retraction, intestine weight and blood glucose of chicks fed with pre-starter feed supplemented with glutamine, after a 24-hour waiting period inside transportation boxes.

\begin{tabular}{|c|c|c|c|c|}
\hline Treatment & Weight (g) & Yolk sac (g) & Intestine (g) & Glucose \\
\hline \multicolumn{5}{|l|}{ Glutamine } \\
\hline $0 \%$ & 43.20 & 3.97 & 2.31 & 296.00 \\
\hline $1 \%$ & 42.66 & 2.72 & 2.43 & 337.00 \\
\hline $2 \%$ & 41.85 & 2.50 & 2.35 & 340.40 \\
\hline $3 \%$ & 42.65 & 2.79 & 2.12 & 324.80 \\
\hline${ }^{*} p$-value & NS & NS & NS & NS \\
\hline${ }^{1} \mathrm{CV}$ & 5.89 & 31.12 & 15.77 & 8.83 \\
\hline
\end{tabular}

*Polynomial regression $(p<0.05){ }^{1}$ Coefficient of variation.

The results of the development of intestinal villi in chicks that consumed feed supplemented with glutamine (Table 4).

According to Maiorka et al. (2016), the heights of villi in the duodenum are most sensitive to glutamine. However, in the present study, supplementation

Table 4 - Evaluation of the development of villi (height of villi, depth of crypts and villus/crypt relationship) in the intestine of chicks fed with pre-starter feed supplemented with glutamine after a 24-hour waiting period in transportation boxes.

\begin{tabular}{lcccccccccc}
\hline & \multicolumn{3}{c}{ Duodenum } & & & Jejunum & \multicolumn{3}{c}{ lleum } \\
\hline Glutamine & Crypts & Villi & V/C & Crypts & Villi & V/C & Crypts & Villi & V/C \\
\hline $0 \%$ & 35 & 256 & 7.19 & 37 & 179 & 4.86 & 33 & 164 & 4.95 \\
$1 \%$ & 38 & 241 & 6.33 & 36 & 147 & 4.13 & 48 & 185 & 3.85 \\
$2 \%$ & 40 & 261 & 6.52 & 34 & 170 & 5.04 & 36 & 176 & 4.94 \\
$3 \%$ & 37 & 208 & 5.58 & 37 & 148 & 4.04 & 36 & 160 & 4.46 \\
\hline${ }^{*} p$-value & NS & NS & NS & NS & NS & NS & $<0,05^{*}$ & NS & NS \\
\hline${ }^{1} \mathrm{CV}$ & 12.43 & 25.73 & 26.52 & 18.07 & 12.29 & 16.67 & 7.53 & 9.99 & 11.95 \\
\hline
\end{tabular}

*Polynomial regression $(p<0.05){ }^{1}$ Coefficient of variation. 
with glutamine only influenced the depth of ileal crypts, presenting a quadratic effect $(p=0,001)$ with maximum peak at $1.44 \%(Y=34.2667+$ 10.600X - 3.66667X2; $R^{2}=0.42$ ). Increasing depth of crypts implies greater rates of cell proliferation and renovation of intestinal epithelium, thereby increasing the number of villi, since these structures originate from the lower part of the crypt (Wang et al., 2008; Fernandes et al., 2017).

Glutamine helps in the growth of intestinal villi, but the mechanism through which this stimulus occurs is not entirely clear. It has been suggested that glutamine might increase the exchange of $\mathrm{Na}+/ \mathrm{H}+$ in the cell membrane, or that it might increase the specific activity of the enzyme ornithine decarboxylase, which is essential for cell proliferation (Rhoads et al., 1997). Moreover, glutamine is a precursor for synthesis of amino acids, nucleotides and nucleic acids (Souba, 1993; Pelícia et al., 2015). It has also been reported that glutamine increases gene transcription, thereby increasing mitogenic activity in the enzyme kinase (Blikslarger \& Roberts, 1997).

Another study using a post-hatch delayed placement/feeding model for broiler chickens showed that the duodenum and jejunum presented complete and maximized recovery of intestinal morphology in chickens that were offered a diet with $1 \%$ glutamine for 48 hours, in comparison with chicken that were kept delayed placement for 48 hours (Yi et al., 2005).

Performance results in the pre-initial phase (Table $5)$. In the present study, feed intake tended to decrease $(p=0.077)$ with increasing glutamine supplementation $\left(Y=168.099-3.47724 X ; R^{2}=0.87\right.$, Linear effect $)$, although there was no reduction in weight gain.

Table 5 - Performance in the pre-starter phase ( 1 to 7 days) among chicks that were given feed supplemented with glutamine.

\begin{tabular}{|c|c|c|c|c|c|c|}
\hline Treatment & Initial weight(g) & Final weight $(\mathrm{g})$ & Weight gain $(\mathrm{g})$ & Daily weight gain (g) & Consumption (g) & Feed conversion $(\mathrm{g} / \mathrm{g})$ \\
\hline \multicolumn{7}{|l|}{ Glutamine } \\
\hline $0 \%$ & 43.02 & 187.07 & 144.05 & 20.57 & 168.14 & 1.07 \\
\hline $1 \%$ & 43.32 & 180.83 & 137.51 & 19.64 & 165.80 & 1.08 \\
\hline $2 \%$ & 42.64 & 182.02 & 139.26 & 19.06 & 158.62 & 1.11 \\
\hline $3 \%$ & 42.80 & 180.96 & 138.06 & 19.24 & 158.94 & 1.10 \\
\hline${ }^{*} p$-value & NS & NS & NS & NS & NS & NS \\
\hline${ }^{1} \mathrm{CV}$ & 1.51 & 4.70 & 6.04 & 8.23 & 3.99 & 4.87 \\
\hline
\end{tabular}

*Polynomial regression $(p<0.05){ }^{1}$ Coefficient of variation.

Studies have shown that there is a positive correlation between the concentration of free glutamine and the rate of protein synthesis in skeletal muscle tissue (Souba, 1993). This means that the greater the concentration of circulating glutamine is, the higher the rate of protein synthesis will be and, consequently, the greater the weight gain will also be. However, this relationship was not observed in the present study. The concentrations at which glutamine is included in the diet are usually higher than those of other additives included in diets. The increases in this concentration to 2 and 3\% may have inhibited the chicks' consumption, thereby masking the metabolic effect of glutamine. Bartell \& Batal (2007), observed that adding $1 \%$ glutamine increased weight gain, while adding $4 \%$ negatively influenced this variable.

Supplementation with glutamine did not influence the retraction of the yolk sac, the absolute intestine weight or the plasma glucose levels that were seen when the chicks reached seven days of age (Table 6). The yolk sac of a recently hatched chick originating from a young bird contains approximately $150 \mathrm{mg}$ of glutamine (Vieira \& Moran, 1999). However, the supplementation of glutamine in this experiment did not lead to better use of the yolk sac by the chicks.

Table 6 - Evaluation of yolk sac retraction and intestinal growth among chicks that were given pre-starter feed supplemented with glutamine, at the age of seven days.

\begin{tabular}{lccc}
\hline Treatment & Yolk sac $(\mathrm{g})$ & IIntestine weight $(\mathrm{g})$ & $\mathrm{Glucose}(\mathrm{mg} / \mathrm{dL})$ \\
\hline Glutamine & & & 338.20 \\
\hline $0 \%$ & 0.45 & 15.68 & 350.20 \\
$1 \%$ & 0.18 & 17.23 & 320.80 \\
$2 \%$ & 0.76 & 14.98 & 345.20 \\
$3 \%$ & 0.22 & 14.77 & $\mathrm{NS}$ \\
${ }^{*} p$-value & $\mathrm{NS}$ & 10.49 & 7.36 \\
\hline${ }^{2} \mathrm{CV}$ & 30.76 & & $\mathrm{NS}$ \\
\hline
\end{tabular}

*Polynomial regression $(p<0.05){ }^{1}$ Weight of the small and large intestines; ${ }^{2}$ Coefficient of variation. 
There was no statistical difference in glutamine concentration in relation to the variables of villus height, crypt depth and villus/crypt ratio when the chicks reached seven days of age (Table 7). Unlike the results from the present study, Maiorka et al. (2000), found that there was an improvement in intestinal mucosal structure among broiler chickens that were fed with $1 \%$ glutamine during their first week of life.

Table 7 - Evaluation of the development of intestinal villi in chicks that were fed with pre-starter feed supplemented with glutamine, at the age of seven days.

\begin{tabular}{|c|c|c|c|c|c|c|}
\hline Treatment & Crypts $^{1}$ & Villi1 & $\mathrm{V} / \mathrm{C}^{1}$ & Crypts $^{1}$ & Villi1 & $\mathrm{V} / \mathrm{C}^{1}$ \\
\hline & \multicolumn{3}{|c|}{ Duodenum } & \multicolumn{3}{|c|}{ Jejunum } \\
\hline \multicolumn{7}{|l|}{ Glutamine } \\
\hline $0 \%$ & 62 & 454 & 7.36 & 60 & 314 & 5.20 \\
\hline $1 \%$ & 61 & 506 & 8.31 & 56 & 317 & 5.66 \\
\hline $2 \%$ & 61 & 364 & 6.00 & 55 & 285 & 5.17 \\
\hline $3 \%$ & 58 & 378 & 6.63 & 63 & 332 & 5.28 \\
\hline${ }^{*} p$-value & NS & NS & NS & NS & NS & NS \\
\hline${ }^{2} \mathrm{CV}$ & 7.86 & 9.74 & 16.09 & 8.46 & 8.04 & 9.76 \\
\hline
\end{tabular}

*Polynomial regression $(p<0.05){ }^{1}$ Crypt depth (crypt, $\left.\mu \mathrm{m}\right)$, villus height (villi, $\left.\mu \mathrm{m}\right)$, villus/crypt ratio (V/C). ${ }^{2}$ Coefficient of variation.

The results from the metabolic assay demonstrated that there were no differences in glutamine concentrations in relation to the variables (Table 8).

The metabolizability coefficients of dry matter, nitrogen and ether extract were not influenced by the supplementation with glutamine ( $p>0.10)$.

It had been assumed that adding glutamine to the diet would improve the digestibility of nutrients, since addition of glutamine is related to increased amylase and trypsin activity, as reported by Tucci et al. (2011), and to increased digestibility of ether extract (Lima et al., 2017). However, Martinez et al. (2012) also did not observe this effect on nutrient digestibility through supplementation with different levels of L-glutamine in the diet of broiler chickens.

Table 8 - Nitrogen balance (NB), ether extract balance (EEB), nitrogen metabolizability coefficient (NMC), ether extract metabolizability coefficient (EEMC) and dry matter metabolizability coefficient (DMMC) of chicks that were fed with prestarter feed supplemented with glutamine, from seven to ten days of age.

\begin{tabular}{lccccc}
\hline Glutamine & NB $(\mathrm{g})$ & EEB $(\mathrm{g})$ & NMC (\%) & EEMC (\%) & DMMC (\%) \\
\hline $0 \%$ & 18.47 & 54.67 & 62.42 & 86.86 & 73.60 \\
$1 \%$ & 13.74 & 53.75 & 51.60 & 88.64 & 72.04 \\
${ }^{2} \%$ & 15.96 & 51.89 & 54.05 & 87.79 & 70.54 \\
${ }^{3} \%$ & 18.40 & 58.19 & 52.58 & 91.74 & 70.54 \\
\hline${ }^{*} p$-value & NS & NS & NS & NS & NS \\
\hline${ }^{1} \mathrm{CV}$ & 21.85 & 15.50 & 9.19 & 2.95 & 4.91 \\
\hline
\end{tabular}

*Polynomial regression $(p<0.05){ }^{1}$ Coefficient of variation.

\section{CONCLUSIONS}

Glutamine concentrations did not differ in relation to performance, histomorphometry of the small intestine or metabolizability of nutrients in the prestarter phase.

\section{REFERENCES}

Bartell SM, Batal AB. The effect of supplemental glutamine on growth performance, development of the gastrointestinal tract, and humoral immune response of broilers. Poultry Science 2007;86(9):1940-1947.

Bhanja SK, Anjali Devi C, Panda AK, Shyam Sunder G. Effect of post hatch feed deprivation on yolk-sac utilization and performance of young broiler chickens. Asian Australasian Journal Animal Science 2009;2(2):1174-1179.
Bhuiyan MM, Gao F, Chee SH, lji PA. Minimising weight loss in new broiler hatchlings through early feeding of simple sugars. Animal Poultry Science 2011;51(11):1002-1007.

Blikslarger AT, Roberts MC. Mechanisms of intestinal mucosal repair. Journal of the American Veterinary Medical Association 1997;211(1):14371441.

Carvalho LSS, Machado CA, Fagundes NS, Litz FH, Abreu Fernandes E de. Biometric development and performance of broilers submitted to different periods of post-hatching fasting. Brazilian Journal of Veterinary Research and Animal Science 2013;50(4):300-306.

Fernandes JIM, Rorig A, Gottardo ET, Schmidt JM, Burin Júnior AM, Fulber LM. Post-hatch diets supplemented with sources of fat and added taurine and glycine on the intestinal morphology and performance of broilers at 1 to 21 days. Brazilian Journal of Veterinary and Animal Science 2017;69(1):198-204.

$\mathrm{Hu}$ CH, Gu LY, Luan ZS, Song J, Zhu K. Effects of montmorillonite-zinc oxide hybrid on performance, diarrhea, intestinal permeability and 
Carvalho FB, Stringhini JH, Leandro NSM, Café M, Sousa RF, Santos BM
Use of Glutamine in Post-Hatch Feed for Broiler

\section{Chicks}

morphology of weanling pigs. Animal Feed Science and Technology 2012;177(1-2):108-115.

Leu WMK, Cotta JTB, Oliveira AIG, Rodrigues PB. Performance of chickens submitted to feed restriction in the initial phase in different rearing systems. Science and Agrotechnology 2002;26(3):610-617.

Lima DCP, Figueirêdo AV, Lopes JB, Silva Costa EM da, Merval RR, Lopes JCO. Digestibility of the diets formulated with different levels of Lglutamine and zinc for broilers. Brazilian Journal of Veterinary Sciences 2017;24(1):86-92.

Maiorka A, Silva AVF, Santin E, Dahlke F, Bruno LDG, Boleli IC, et al. Effect of broiler breeder age and glutamine supplementation on the development of the intestinal mucosa of 7-day-old chicks. Brazilian Journal of Poultry Science 2016;18(1):17-22.

Maiorka A, Silva AVF, Santin E, Borges SA, Boleli IC, Macari M. Influence of glutamine supplementation on performance and intestinal villous and crypt development in broiler chickens. Brazilian Journal of Veterinary and Animal Science 2000;52(5):487-490.

Martinez KLDA, Leandro NSM, Café MB, Stringhini JH, Araújo ICSD, Andrade MA. Supplementation of glutamine in diets with ingredients from animal and vegetable sources for broiler chicks. Brazilian Journal of Veterinary and Animal Science 2012;64(6):1707-1716.

Pelícia VC, Ducatti C, Araujo PCD, Stradiotti AC, Aoyagi MM, Fernandes BDS, et al. Trophic action of phytogenic additives, glutamine and glutamic acid on Bursa Fabricii and small intestine of broilers. Brazilian Journal of Veterinary Research 2015;35(7):691-699.

Rhoads, JM, Argenzio RA, Chen W. L-glutamine stimulates intestinal cell proliferation and activates mitogen-activated protein kinases. American Journal of Physiology 1997;272(5):943-953.

Ribeiro Junior VR, CLN, Messias RKG, Rocha TCl. Metabolismo e suplementação dietética de glutamina em dietas de aves. Nutritime 2015;12(5):4320-4332.
Rostagno HS, Albino LFT, Donzele JL, Gomes PC, Oliveira RD, Lopes DC, et al. Tabela brasileira para aves e suínos: composição de alimentos e exigência nutricional. Viçosa: Editora UFV; 2005.

SAEG. Saeg: Sistema de análises estatísticas e genéticas. Viçosa: UFV; 2007.

Silva DJ, Queiroz AC. Análise de alimentos: métodos químicos e biológicos. $3^{\text {rd }}$ ed. Viçosa: Editora UFV; 2002.

Souba WW. Intestinal glutamine metabolism and nutrition. The Journal of Nutritional Biochemistry 1993;4:2-9.

Sousa DC, Oliveira NL, Santos ET, Guzzi A, Dourado LR, Ferreira GJ. Morphological characterization of the gastrointestinal tract of Cobb $500^{\circledR}$ broilers. Brazilian Journal of Veterinary Research 2015;35 Supl 1:61-68.

Tucci FM, Thomaz MC, Júnior JMP, Hannas MI, Scandolera AJ, Budiño FEL. Trofic agents in the diet of weaned pigs on the activity of the digestive enzymes and the performance. Brazilian Journal of Veterinary Research and Animal Science 2011;48(4):289-298.

Van den Brand H, Molenaar R, Van der Star I, Meijerhof R. Early feeding affects resistance against cold exposure in young broiler chickens. Poultry Science 2010;89(4):716-720.

Vieira, SL, Moran ET. Effect of egg origin and chick post-hatch nutrition on broiler live performance and meat yields. World's Poultry Science Journal 1999;55(2):125-142.

Wang J, Chen L, Li P, Li X, Zhou H, Wang F, et al. Gene expression is altered in piglet small intestine by weaning and dietary glutamine supplementation. The Journal of Nutrition 2008;138(6):1025-1032.

Yi GF, Allee GL, Knight CD, Dibner JJ. Impact of glutamine and oasis hatchling supplement on growth performance, small intestinal morphology, and immune response of broilers vaccinated and challenged with Eimeria maxima. Poultry Science 2005;84(2):283-293. 
